\title{
Tax Evasion and Economic Crime. Empirical Evidence for Italy
}

\author{
Amedeo Argentiero \\ Bruno Chiarini \\ Elisabetta Marzano
}

CESIFO WORKING PAPER NO. 5497

CATEgORY 1: Public FinANCE

SEPTEMBER 2015

An electronic version of the paper may be downloaded

- from the SSRN website:

wWw.SSRN.com

- from the RePEc website:

- from the CESifo website:

www.RePEc.org

www.CESifo-group.org/wp 


\title{
Tax Evasion and Economic Crime. Empirical Evidence for Italy
}

\begin{abstract}
This paper examines the impact of tax evasion on criminal activities in Italy. Precisely, we consider three types of crime particularly related to economic determinants: property crimes (including robberies, thefts and car thefts), frauds and usury. By using annual data for the Italian provinces (NUTS-3) over the period 2006 to 2010 to estimate a dynamic panel, we show that tax evasion substitutes both, frauds and usury, whereas crimes against the property are positively affected by tax evasion. Interestingly, the degree of substitution for fraud and usury is related to the size of tax burden. Moreover, the estimates indicate that these crimes show a different persistency over time, reflecting different adjustment costs. Finally, we find statistical significance and the expected sign for deterrence only for property crimes whereas frauds and usury are not influenced by any deterrence or clearing-up variable.
\end{abstract}

JEL-Code: C330, K340, K420.

Keywords: property crime, usury, frauds, tax evasion, deterrence effect.

\author{
Amedeo Argentiero \\ University of Perugia \\ Department of Economics \\ Perugia / Italy \\ amedeo.argentiero@gmail.com
}

\author{
Bruno Chiarini* \\ University of Naples Parthenope \\ Department of Economics and Legal \\ Studies / Naples / Italy \\ bruno.chiarini@uniparthenope.it
}

\author{
Elisabetta Marzano \\ University of Naples Parthenope \\ Department of Economics and Legal Studies \\ Naples / Italy \\ elisabetta.marzano@uniparthenope
}

*corresponding author

\begin{abstract}
August 2015
We thank Roberto Golinelli, Stefano Pisani and Guido Rey for suggestions on the previous versions of this paper. We are also especially grateful to Antonella Baldassarini (ISTAT), Antonio Cortese (ISTAT), Paolo Acciari (Italian Ministry of Finance) and Sauro Mocetti (Bank of Italy) for providing us data and suggestions. A previous version of this paper has been presented at the Conference on "Multiple Perspectives of the Shadow Economy" held in Porto (Portugal) on November 2014 and at the workshop on "The economic dimension of crime" held in Rome on February 2015 at the National Council for Economy and Labour (CNEL). We have also benefited of comments from the participants at the seminar held at the Italian Revenue Agency in May 2015 and at the conference "Shadow 2015" held in Exeter in July 2015. This work is the result of a collaboration of the authors and the University of Naples Parthenope with the Italian Revenue Agency. We thank the Agency for providing us the data on tax gap and for the permission to publish the research results obtained by processing them. The opinions expressed in the paper are only ours and we are the solely responsible for all the errors.
\end{abstract}




\section{Introduction}

In recent years, the economics of crime have shifted the analysis from a Becker's crime economic framework, based on the relationship between crime and punishment, to a more "flexible" approach where many demographic and socioeconomic variables have a role in the explanation of crime.

This literature has proved that crime is often linked to unemployment, age and gender composition of population, education, income, employment activity etc. In this empirical context also several deterrence variables which approximate the probability and the severity of punishment are often significant. ${ }^{2}$ In this paper we investigate whether, in a country characterized by high underground activity and tax evasion, there is an increasing presence of criminality. Although an extensive literature in economics has examined the determinants of crime, the role of underground economy has not received due attention. Precisely, our research question is the following one: considered the quantitative importance of the underground economy and tax evasion in Italy, can tax evasion be seen a determining variable for criminal activity?

We consider three types of crime particularly related to economic determinants: i) property crimes, which include robberies, thefts and car thefts; ii) frauds and iii) usury. These are crimes that have a strong impact on the economic and social structure of the affected areas and are usually linked, by the literature, to socio-economic and demographic determinants, neglecting the role of the underground economy and, therefore, of tax evasion. Why tax evasion can be considered a determinant of the economic crimes? We may think that criminal activities might be indirectly shaped by tax evasion for several reasons. A first one is the income-redistribution which tax evasion generates towards any income that is not clearly attributable and subject to withholding tax. In recent decades, in a context of continuing increases in the tax burden, a massive tax evasion of small businesses, artisans, shopkeepers, merchants and professionals has generated strong inequalities that may have impacted on criminal activity. A strong redistribution of income towards the self-employed and small businesses produces an inevitable increase in inequality that impacts on property crimes (see for instance, Fajnzylber et al., 2002). A second factor that binds the two phenomena into account is the wealth effect. Tax evasion, though obscure to the Revenue Agency, is well perceived in the territories, and may induce agents to commit more crime. Finally, a third

\footnotetext{
${ }^{2}$ See Buonanno (2003) and Buonanno and Montolio (2008) for a survey. For an analysis of crime in Italy see Marselli and Vannini (1997), Buonanno and Leonida (2006), Cracolici and Uberti (2008) and Bianchi et al (2012) amongst others.
} 
factor concerns the criminogenic environment that a growth of informality produces: if entrepreneurship and legal work are far less lucrative than the irregular one, the growth of the underground activities can generate a culture of illegality where the potential gain for the criminals is fully recognized.

These factors seems to predict a positive effect of tax evasion on crime. However, important substitution effects may arise between crimes and tax evasion, since this latter is a reward only benefited from legitimate work. Moreover, when tax evasion is placed in relation to specific economic crime such as usury and frauds, increasing the unreported income to the fiscal authorities may negatively affect crime since both the phenomena contribute to the same purpose: to finance legal activities of households and small firms.

In order to investigate these complex dynamics, we exploit a new data set on tax gap, provided by the Italian Revenue Agency (Agenzia delle Entrate), together with many socioeconomic and demographic control variables.

We estimate a dynamic panel model following Arellano-Bond (1991) and Arellano-Bover (1995) procedure for the Italian provinces (NUTS-3) from 2006 to 2010.

Using data for the Italian provinces, tax evasion is found to be an important determinant of the selected crimes. Interestingly, while tax evasion turns out to be a substitute for frauds and usury it is positively correlated with property crimes.

Another interesting finding concerns the substitution effect, that is an increasing function of the tax burden. The estimates also indicate that the selected crimes show a different persistency over time, reflecting different adjustment costs. Finally, we find statistical significance and expected sign for the deterrence variable in property crimes whereas frauds and usury are not influenced by any deterrence or clearing-up variable.

The paper is structured as follows. The next section sketches the theoretical models useful to interpret how the behaviors of different economic crimes may be differently affected by tax evasion, clarifying the expected signs of the variables involved. Section 3 is a brief report on the stylized facts concerning the crimes involved and tax evasion. Section 4 provides a description of the data used in the empirical analysis. Section 5 shows the methodology used and in the next sections 6 the empirical results are presented and interpreted. Finally, section 7 concludes the analysis. An appendix contains the calculation method of the Italian Revenue Agency for the tax gap at the provincial level. 


\section{Crime behaviour and markets involved: a simple theoretical scheme}

The economic literature on crime is mainly based on the framework set out by Gary Becker (1968). The idea is that would be criminals rationally weigh up the expected costs and benefits of breaking the rules. If the probability of being caught or the level of fine is too low, then the expected costs might be outweighed by the benefits. In this case, choosing crime can be rational and the related activities can be profitable.

It is obvious that theft and robbery, usury and fraud are quite different criminal activities with different determinants, entailing a different type of choice and impinging on different markets. Here we outline a theoretical framework to interpret the empirical results presented in the following sections.

Viewed through the lenses of the standard economic model of decision-making, individuals choose between criminal activity and legal activity on the basis of the expected utility from those actions. If $S$ is the gain (wage, income) from successful crime, $p$ the probability of being apprehended, $F$ the extent of punishment, and $\mathrm{W}$ is earnings from legitimate work, the decision-maker will choose to commit crimes in a given time period rather than do legitimate work when:

$$
(1-p) U(S)-p U(F)>U(W)
$$

Amongst the empirical implications of this framework the following deserve attention. ${ }^{3}$ The attitudes toward risk is measured by the curvature of $U$ and will impinge on the decision to commit crimes: risk averse persons will respond more to changes in the chances of being apprehended than to changes in the extent of punishment, holding fixed the expected net income from crime $((1-p) S-p F-W)$. A further implication is that crime must pay a higher wage (income) than legal activities. Thus, as $p$ rises, the gap between $S$ and $W$ must increase to maintain the advantage of crime. Successful crime must pay off more the greater the chance of being be caught and arrested. Lastly, Equation (1) shows that the major factors that affect the decisions to commit a crime - criminal versus legal earnings, the chance of being caught, and the severity of the sentence are intrinsically related.

\footnotetext{
${ }^{3}$ See amongst others Freeman (1999).
} 
Although the model highlights the key variables on which most empirical work focuses, it can be expanded in various ways to allow for socio and demographic variables which characterize the social context and the labor market. Thus, the maximization of the above expected utility provides a supply curves of crime:

$$
C=C(S, p, F, W, \Phi)
$$

where $\Phi$ is a vector of portmanteau variables representing other influences.

This is a scheme of two activites, that treats crime and legal work as substitutes. Of course this simple relationship may be generalized, one can commit crimes while holding a legal job or can shift from crime to legal work and back again, depending on relative convenience. In this regard, we may assume two supply curves in the labor market, a legal one (with a salary) and an illegal one (with the proceeds of crime).

Regarding the demand side, it is possible that in the criminal market there exists a downward sloping relation between numbers of crimes and criminal earnings. Certainly, the amount of the victims of crime should be negatively related to the advantages of criminal behavior or to the expected reward to crime in a demand type relation. In fact, institutional authorities may push for increasing $\mathrm{p}$ or $\mathrm{F}$, cutting the rewards to crime. Moreover, as criminals commit more crimes, they will move from more lucrative crimes to less lucrative ones (according to a standard decreasing marginal utility principle). An upward sloping supply curve to crime and downward sloping "demand" relation produce a market clearing level of crime and rewards to crime, comparable to the market clearing wages and employment for other occupations or industries.

\subsection{The role of tax evasion on property crimes and frauds}

The approach adopted here follows the economists' usual analysis of choice. A person who commits a crime against the property (theft and robbery) and a fraud falls within this framework but with some caveats, to capture the role of tax evasion, which concerns the earnings from legitimate work. Generally speaking, in the presence of weak tax enforcement, "legitimate" after-tax earnings are positively affected by tax evasion.

We may ask how the phenomenon of tax evasion enters this framework. One of the reasons why tax evasion may affect property crimes is that when the victims of these crimes are tax-evaders, they have less incentive to report the crime suffered thus generating a reduction in the chance of being caught and the extent of sentencing. From this point of view, the relationship property crimes-tax evasion is of "Beckerian" nature and qualifies the offer of crime. In the Becker's model (1968), the 
strength of the police and the judicial system increases the probability of apprehension and the punishment for criminal actions ( $p$ increases), thus reducing the incentive for an individual to commit a crime. This is the crime deterrence effect. The dodgers, in this context, having an incentive not to report the crime, reduce this probability $p$.

The supply of offenses (or the crime rate) would be an increasing function of the return per offense with an upper-sloping schedule: as the remuneration in the criminal market rises $(S)$ supplied hours $\left(N^{\text {Crime }}\right)$ rise too. In addition, the labour supply in the criminal market shifts according to the other relevant variables in Equation (2). Precisely, when tax evasion rises, the probability of conviction per offense declines, because tax-evaders have no incentive to report the crime suffered and hence labour supply in the Figure 1 translates rightward: for a given remuneration of successful crime, the expected net income rises and it is optimal to supply additional hours.

Figure 1: Property crime: labor supply and the effect of tax evasion

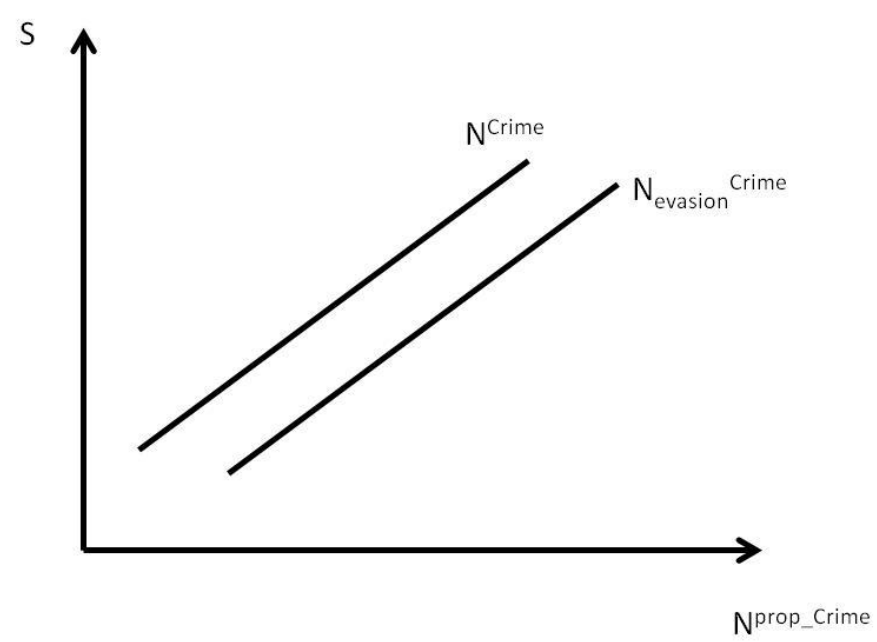

Therefore, with regard to crimes against the property, it should be noted that the low wages in the legal labor market, received by those who commit this type of crimes, do not produce incentive to evade taxes. In other words, we can guess that people who commit this crime are not involved in tax evasion.

Another reason that justifies the inclusion of tax evasion in the Backer's scheme comes from the extension made by Ehrlich (1973) who considers how income levels and distribution may affect propensity and crime rate. He argues that payoffs to crime, especially property crime, depend primarily on the opportunities provided by potential victims of crime, as measured by the median income of the families in a given community. In his econometric analysis, he found that a measure of income inequality - the percentage of families below one-half of the median income - is also associated with higher crime rates.

Furthermore, tax evasion in Italy has generated over the years a strong redistribution of income by increasing the income inequality and, therefore, may cause an increase in the crime rate (a right 
ward shift in Figure 1). Finally, since tax evasion also improve the wealth of other members of society, the size of the potential loot from crime also rises ( $\mathrm{S}$ in the utility function increases, in this case we deal with a movement on the same crime-supply curve).

In frauds, it is plausible that wages obtained from working in the legal market are higher than the "subsistence level" and then allow people to "cheat" the State. Certainly, we are talking about a different individual from the one who commits theft and robberies.

In this case, a person who is willing to commit the crime should allocate the "working time" between legal and illegal activities, but he must select an optimal choice between defrauding the State (tax evasion) when offering legal work or cheating (for instance) in a market with asymmetric information (frauds). Contrary to the case of theft and robbery, here tax evasion is of interest for people who commit crime and this implies that there could be two supply curves in the labour market, a legal one (with a salary) and an illegal one (with the proceeds of crime).

The labour supply in the fraud market is positively sloped: as the remuneration in the fraud market rises $(S)$ the supplied hours $\left(N^{\text {Crime }}\right)$ rise too. In addition, labour supply in the fraud market shifts leftward as long as tax evasion rises: in the presence of tax evasion the alternative use of time becomes more attractive, and the supply in the fraud market declines.

\section{Figure 2. Frauds: labor supply and the effect of tax evasion}

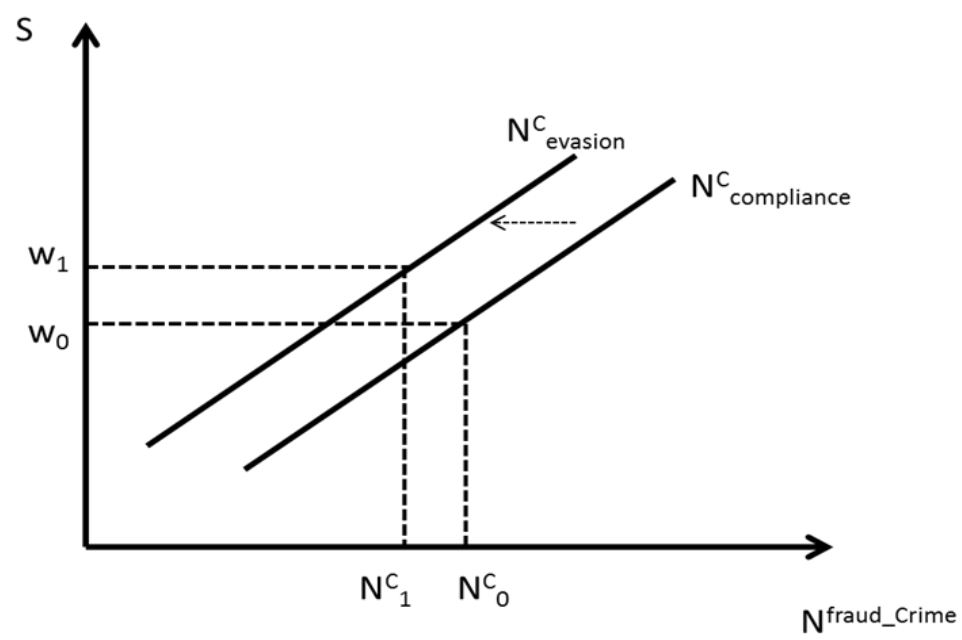

We can briefly explain this shift as follows. We assume an arbitrage mechanism between the legal and fraud market. In other words, in equilibrium the illegal wage $S^{C}$ is equal to the after-tax (net of taxes and social security contributions) wage paid in the legal market w, so that we can examine the effects of tax evasion on the supply of criminal hours, as depicted in Figure 2. 
If the after-tax wage in the legal market is $\mathrm{w}_{0}$, and there is no tax evasion, the labor supply in the fraud market reaches its high, represented by the schedule $N_{\text {compliance }}^{C}$ Now, when an arbitrage is possible between the two markets (legal and illegal), the individual optimally supplies $N_{0}{ }^{C}$ hours in frauds 'activities.

In the presence of tax evasion, there are two effects to be accounted in the fraud market: i) the legal expected net wage, relevant for the assumed arbitrage condition, rises because of tax evasion $\left(\mathrm{w}_{1}\right.$ in Figure 2); ii) the higher remuneration in the legal market generates an leftward movement in the labor supply schedule in the fraud market, that shifts the same schedule in the position $N_{\text {evasion }}^{C}$. This movement accounts for the substitution effect between the criminal activities and tax evasion. Jointly taken, these two effects plausibly yield a decline in the optimal level of hours supplied in the fraud activities, from $N_{0}{ }^{C}$ to $N_{l}{ }^{C}$.

This simple scheme, although consistent with a Beckerian analysis of crimes, suggests that the response to tax evasion is very different depending upon the specific crime under consideration.

As long as tax evasion rises, it can be optimal for the thief/burglar to supply a larger number of hours in the criminal market. Conversely, a different individual, who has a legal job, optimally supplies a lower number of hours into the illegal market, reducing frauds, when he engages in tax evasion.

\subsection{The effects of tax evasion on the demand of usury}

We have seen that the bulk of the empirical research on the economics of crime focuses on factors that affect the supply of criminal activities. For some economic crimes it is however important to focus on the demand for criminal activity.

This is the case of the crime of usury; the peculiar aspect of this crime leaves to foresight that the supply is infinitive elastic for the relevant demand size. Figure 3 (where on the axes are shown the illegal interest rate, $r$, and the usurer amount of loans) shows that the quantity exchanged can be predominantly attributed to the short side of the market (demand). 


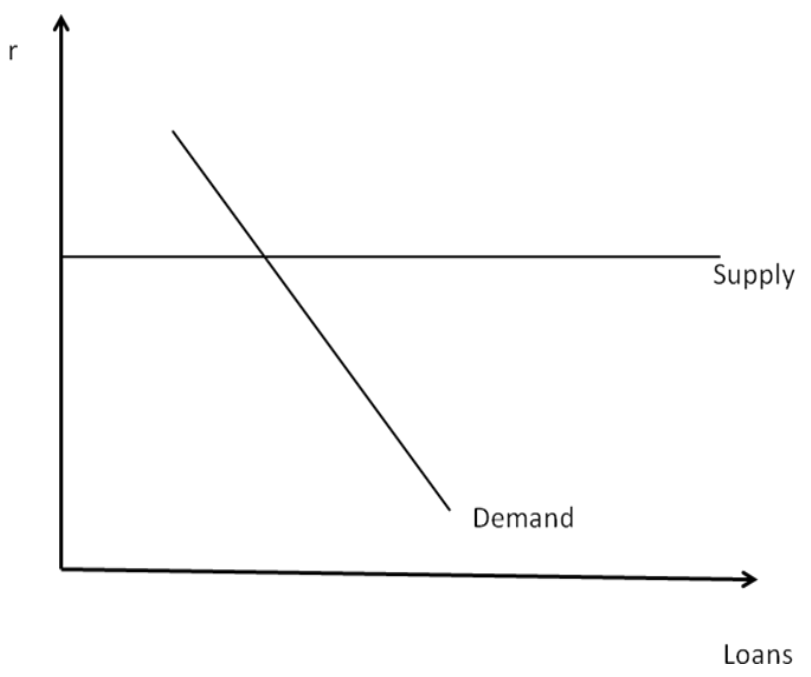

In Italy this type of crime affects mainly small business owners, shopkeepers and professionals. It is important to stress that these economic categories, which constitute the main part of the Italian production system, are also heavily involved with tax evasion (see Relazione Corte dei Conti, 2014) and, at the same time, are themselves subject to the restrictions on credit exercised by the banking system. These small and micro firms determine the demand for usury.

Given the financial instruments (legal and illegal) available to the entrepreneurs for a given level of investment $I$, by choosing the level of tax compliance $Y^{R E P O R T E D}$, each entrepreneur faces the following consequences:

a) paying the tax liabilities on $Y^{\text {REPORTED }}$;

b) deciding the maximum amount of legal loans as a function of the reported revenues $L\left(Y^{\text {REPORTED }}\right)$;

c) pocketing the tax wedge on the unreported output, $\tau \cdot\left(Y-Y^{\text {REPORTED }}\right)=\tau \cdot Y^{\text {UNREPORTED }}$;

d) using the resulting tax evasion of c) as a self-financing device.

The demand of usury is endogenously determined, as a residual funding demand and upon the level of credit rationing.

Although it is quite simple to derive the accounting costs of any possible combination of funding alternatives (the amount of any kind of sum borrowed times the respective interest rate) it is important to take into account the economic cost as well. Actually, in the case of the banking loans, the accounting cost and the economic cost can differ significantly. Beyond the interest rate charged, banks usually require a collateral. To be eligible for banking credit, the entrepreneur has to report 
his revenues to fiscal authorities, since it is plausible to assume that the accepted collateral is an increasing function of the official production. Therefore, from an economic point of view, the cost of the banking credit is the charged interest rate (accounting cost) plus the opportunity cost of tax compliance. It is realistic to assume that the opportunity cost of tax compliance is a function of the tax burden: every time the entrepreneur pays the due tax liabilities, he is giving up the same amount in terms of self-financing. Therefore, the price per unit of compliance is simply given by the evasion-to-compliance ratio, that can be proxied by the tax gap, whose characteristics will be better described in the next section.

Hence, we can model the optimal financial structure, and therefore the demand for usury loans, as a problem of optimal choice between two alternative goods: usury funding and tax compliance, knowing that the opportunity cost of tax compliance is the tax gap. Precisely, it is a problem of costs minimization with the level of desired investment as constraint to the optimization. The investment is a function of the available funding in the legal and illegal markets. The firm/entrepreneur can mix according to his preferences three funding alternatives: bank loans $\left(L^{B A N K}\right)$, tax evasion (TaxEvasion), that represents a self-financing device, and usury funding $\left(L^{U S U R Y}\right)$ :

$$
I=L^{\text {Bank }}+L^{\text {Usury }}+\text { TaxEvasion }
$$

Bank credit is provided as an increasing share of tax compliance, while the amount of tax evasion which finances investments depends upon the tax enforcement regime. Equation (3) may be written as follows:

$$
I=L\left(Y^{\text {Re ported }}\right)+L^{\text {Usury }}+E\left(Y^{\text {UNREPORTED }}\right)
$$

In other words: given the amount of investment and the level of tax compliance, the size of regular credit is fixed by the loans provision $L($.), whereas self-financing through tax evasion depends upon the degree of enforcement $E($.$) ; any additional funding can be only provided by the usury financial$ market.

By solving a constrained optimization problem, it is possible to model, for a given level of investment, the optimal choice of tax compliance/bank loans and usury, deriving a demand for usury loans. The demand schedule for usury reported in Figure 3 is negatively sloped as usual, but, in addition, the position of the demand for illegal loans can change depending upon the level of planned investment as well as according to the level of the price of the alternative source of funding, namely tax compliance, whose economic cost is the tax gap. It is well known that the demand of each good can be positively, negatively or not affected by the price of another good, if 
this latter can be, respectively, a substitute a complement or nor correlated with the former. When usury and tax compliance are substitutes, an increase in the price of tax compliance, i.e. the tax gap, also generates a rightward shift in the demand for usury. Put differently, the reduced credit provision, triggered by the lower compliance, has to be compensated by either tax evasion and usury. Conversely, when usury and tax compliance are complement, the rise in the tax gap would shift leftward the demand for usury: the increase in tax evasion is able to offset the lower credit provision and also allows to reduce criminal funding.

In the presence of a frictionless credit market, and high enforcement regime, a larger tax compliance will also mean a larger probability to be supported by the credit market, whereas the expected rewards from tax evasion are low. In this case, a positive relationship is expected between tax evasion and usury demand. Conversely, if credit rationing arises, and tax enforcement is weak, it is more likely that small and micro firms will use as substitutes illegal funding from usury and the one from tax evasion. In this latter situation, the demand for usury would be negatively affected by an increase in the opportunity cost of tax compliance, as it is represented in Figure 4, where we simulate an increase in the level of the tax gap from $t \_g a p *$ to $t \_g a p * *$.

Figure 4. Usury loans market equilibrium after an increase in the tax gap (usury and tax compliance are complements)

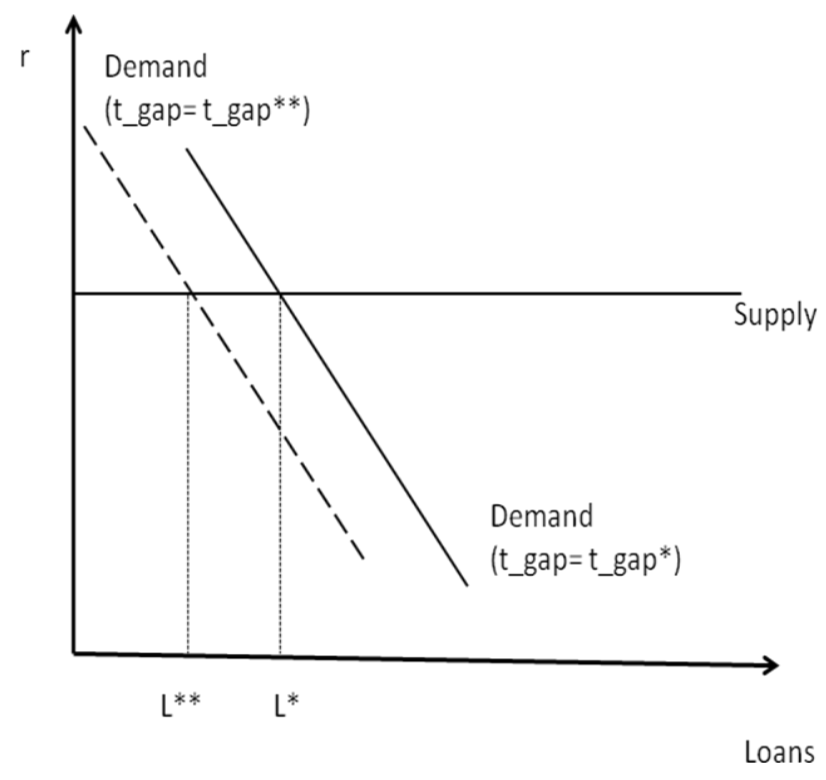

The theoretical models outlined here are useful instruments to interpret how the behaviors of different economic crimes may be differently affected by tax evasion. In particular, these schemes 
are useful to define the expected signs of the variables involved. In the following sections we will proceed with the empirical analysis by describing the data-set and models estimated.

\section{Some stylized facts about the economic crimes and tax evasion}

\subsection{Economic crimes}

As Figure 5 shows, the selected crimes (offences against property, fraud and usury) account for more than $46 \%$ of total crimes in Italy in 2006 and rise to $62 \%$ in 2010. Moreover, there is an upward and significant trend in crimes against the property, rising from a low of $27 \%$ in 2006 to a peak of $43 \%$ in 2011, that can be certainly explained by the deep recession that is still experiencing Italy, with a first deep through in 2009. Crimes against property (robberies and thefts) and fraud account for almost all of the criminal activities involving redistributive conduct (92-95\%). Conversely, among the economic crimes related to production activities, usury is quantitatively less important, about $1 \%$ in the observed time period. However, it must be stressed that one of the biggest problem in fighting usury crimes is the low rate of crime's reporting. In this sense, the number of complaints submitted to the court does not give a reliable measure of the true extent of the problem. ${ }^{4}$

These crimes may also not imply severe penalties for the offender (for instance, many years in prison), but (as it well known) they have serious negative spillovers effects on the economy.

It is suffice to recall, for example, how usury is intertwined with the credit market, deeply affecting it in some contexts, and how important usurer's debit contracts are in a country of about 5 million small businesses and micro firms, often facing financing constraints pushing them to look for nonbank finance alternatives.

Similarly, the importance of fraud on the economy, which resides on asymmetric information, is testified by the most common crimes reported by victims: credit card fraud, false accounting manipulation of accounts and accounting records, insurance fraud, mortgage fraud, payroll fraud, pyramid schemes, bogus invoices, counterfeiting, forgery, copyright abuse, to name a few. ${ }^{5}$

\footnotetext{
4 In this regard, the National Statistics Institute estimates that only $35 \%$ of property crimes are reported to the authorities, whereas for frauds and usury there is no official estimate.

${ }^{5}$ An agent is said to have committed fraud when he misrepresents the information he has at his disposal so as to persuade another individual (principle) to choose a course of action he would not have chosen had he been properly informed (see Karni, 1989).
} 


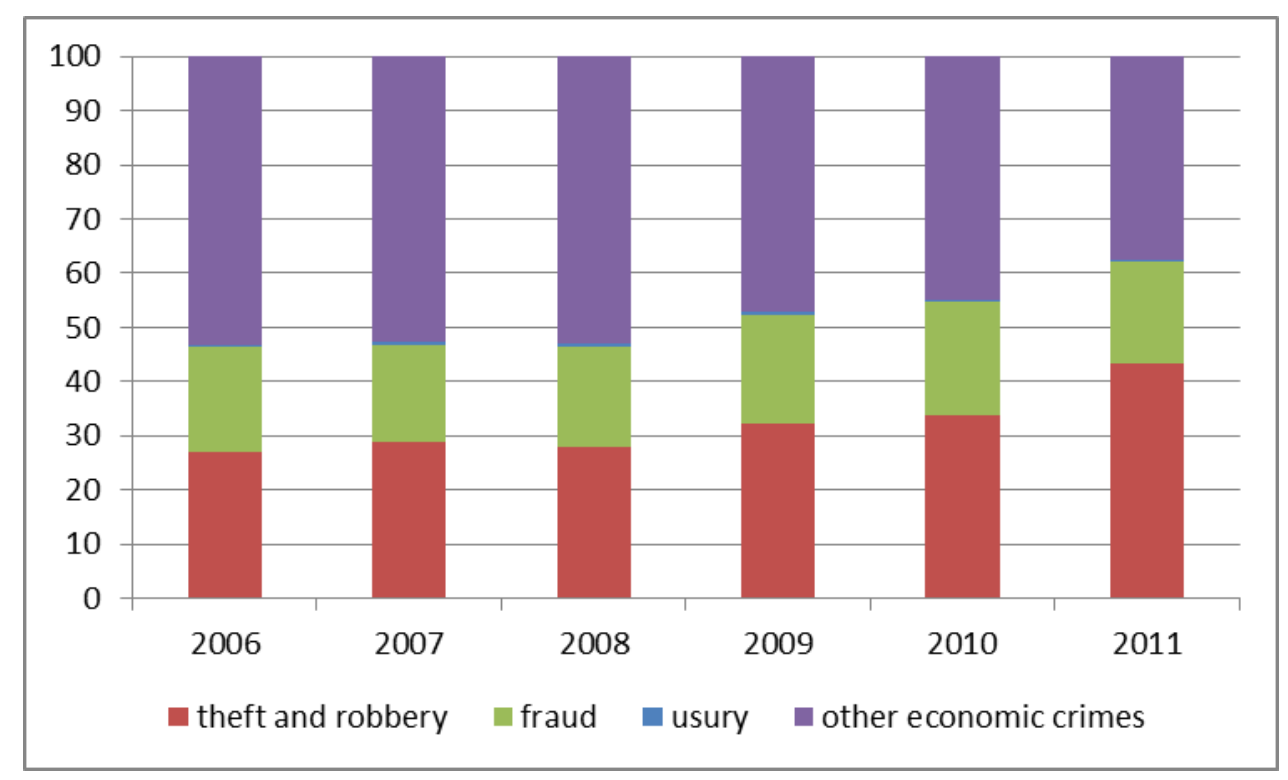

\subsection{Tax evasion}

Cheating the government is a thriving practice in most countries, and in particular in Italy where latest official estimates indicate a figure of about 250 billion euro for the value added tax base hidden to the Revenue Agency. ${ }^{6}$ The National Institute of Statistics, consistent with international standards and, in particular, with the 1995 System of National Accounts, estimates and regularly updated a time series of the size of the underground economy from 2000, and indicate an hidden production over $16 \%$ of the total GDP. Using the tax gap data on provincial base, provided by the Revenue Agency, we firstly explore the importance of tax evasion for the three typologies of economic crime listed above.

Table 1 reports the evolution of the tax gap (difference between the potential collection and the tax that is actually paid) over the period 2006-2010 in terms of the main descriptive statistics. ${ }^{7}$ On average, in Italian provinces, during the examined period, 2006-2010, about 1400 euro per capita of tax receipts are concealed to tax authorities.

\footnotetext{
${ }^{6}$ Ministero dell'Economia e delle Finanze (2013).

${ }^{7}$ In Appendix, we briefly report the methodology used by the Italian Revenue Agency for the construction of the tax gap.
} 
Table 1: per capita (euros) tax gap, Italian Province, years 2006-2010

\begin{tabular}{|c|c|c|c|c|c|}
\hline year & mean & Min & max & median & sd \\
\hline 2006 & 1465.5 & 616.5 & 3719.7 & 1386.9 & 517.2 \\
\hline 2007 & 1300.7 & 610.5 & 2945.7 & 1297.3 & 452.5 \\
\hline 2008 & 1451.1 & 523.7 & 3611.4 & 1411.3 & 523.8 \\
\hline 2009 & 1448.1 & 552.6 & 3048.6 & 1359.3 & 517.6 \\
\hline 2010 & 1387.9 & 546.8 & 2862.6 & 1326.5 & 487.6 \\
\hline
\end{tabular}

The figures in the table show that, although with a significant variability between the minimum and maximum values observed between the various Italian provinces, the phenomenon appears quite relevant and persistent, despite the fact that during the period examined, the Revenue Agency has achieved good results in the fight against tax evasion. In fact, in the years considered (2006-2010), the number of investigations of the activities of tax evasion increased from 420 to 705 thousand. The number of investigations, thanks to the selection of the subjects made on the basis of risk analysis for each type of taxpayer and the strong use of the Agency databases, are becoming more targeted, so that, in 2009 and 2010 in the face of a number of investigations basically stable, the additional tax assessed reported a sharp increase. The tax assessed rose from 13 billion euro in 2006 to about 28 billion in 2010. Similarly to that recorded for the additional tax assessed, the total collections from tax evasion show a systematically dynamic increasing over the period (from 4 to about 11 billion euro). In particular, it should be noted the significant collections of the years 2009 and 2010, where the revenue collected has remarkably increased, despite the economic crisis. (see Agenzia delle Entrate 2010).

The propensity to tax evasion, reported in Table 2 below, is calculated using the ratio between tax gap and tax compliance in each Italian province: $\frac{\text { taxgap }}{\text { taxcompliance }}$. 
Table 2: Propensity to Evade (\% of tax compliance), Italian Province, years 2006-2010

\begin{tabular}{|c|c|c|c|c|c|}
\hline year & mean & Min & max & median & sd \\
\hline 2006 & 48.02 & 10.16 & 145.2 & 38.53 & 27.64 \\
\hline 2007 & 40.67 & 9.24 & 122.5 & 31.54 & 24.54 \\
\hline 2008 & 43.62 & 11.74 & 114.48 & 36.44 & 24.22 \\
\hline 2009 & 47.87 & 10.86 & 118.44 & 42.23 & 24.27 \\
\hline 2010 & 44.57 & 9.85 & 119.73 & 40.19 & 22.58 \\
\hline
\end{tabular}

The table highlights several important stylized facts concerning the variability, the dynamics and the size of tax evasion in the Italian provinces. First, what stood out instantly, is the enormous size of the propensity to evade: in 2010, a magnitude equal to about $50 \%$ of the tax compliance is, on average, hidden to the tax authorities in the Italian provinces. Second, there is a huge variability among Italian provinces, with a minimum share of tax evasion on tax compliance of about $10 \%$ and a maximum closer to $120 \%$ : in some areas of Italy, tax evasion is by far larger than tax compliance. Third, the propensity to evade looks surprisingly stable over the years of the sample considered, although there is a significant reduction between 2006 and 2007. Finally, the dynamics of the propensity to evade is characterized both by the business cycle and tax evasion: in fact tax evasion increases, when the recession becomes more severe (with a consequent reduction in the value added and the reported tax base) in 2008 and 2009, while, with the beginning of the recovery in 2010 the ratio lowers again

\section{Data and explanatory variables}

In addition to the tax gap, our panel dataset contains annual observations from 101 Italian provinces over the period 2006 to 2010. The dependent variable concerning the crime data are from the Italian National Statistical Institute (ISTAT, Statistiche Giudiziarie e Penali). Precisely, our crime variable is the number of crimes reported to the judicial authorities. We perform three model regressions distinguishing between property crime which includes robberies, thefts and car thefts, fraud crimes, and usury crimes. All the crime variables are normalized per thousand inhabitants.

Regarding tax evasion, we consider the propensity to evade given by the ratio between tax gap and tax compliance This latter is measured by the spontaneous fiscal revenues in each province In the 
literature on crime models, usually, GDP or value added are both considered as proxy for the general level of prosperity. This fact has led us to use, as alternative measure of the propensity to evade taxes, the ratio between tax-gap and value added in each province (Section 7.8 below), rather than the absolute value of the tax gap, which would be collinear with the value added and thus obscuring the individual effects on crimes (Figure 6). However, the use of the value added, in addition to the problem of collinearity mentioned above, leads to a biased view of the propensity to evade taxes because it contains an estimate of the underground economy. Moreover, the value added data do not take into account the difference between the firms' production area and their registered office.

Finally, to get an idea of the difference between the two indicators of tax evasion mentioned above, we have to bear in mind that the propensity to evade measured in terms of value added can be rewritten in the following way:

$$
\frac{\text { taxgap }}{\text { value added }}=\frac{\text { taxgap }}{\text { taxcompliance }} \cdot \frac{\text { taxcompliance }}{\text { value added }}
$$

This way of interpreting the effect of the new propensity to evade is quite convenient as it allows us to identify a first component which is the propensity to evade in terms of tax compliance, the tax gap/tax compliance ratio, and a second component which is a measure of the tax burden. Hence, the propensity to evade as a share of value added includes also the size of tax burden, thus generating an increase in the ratio $\frac{\text { taxgap }}{\text { value added }}$ when tax burden grows, for a given value of $\frac{\text { taxgap }}{\text { taxcompliance }}$. For all these reasons, to isolate the most the effect of tax evasion, we prefer, as reference variable, the tax compliance, although the estimates using the value added provide us interesting additional information on the relationship with economic crimes. 
Figure 6. Scatter plot Tax Gap-Value Added in the Italian provinces (logs)

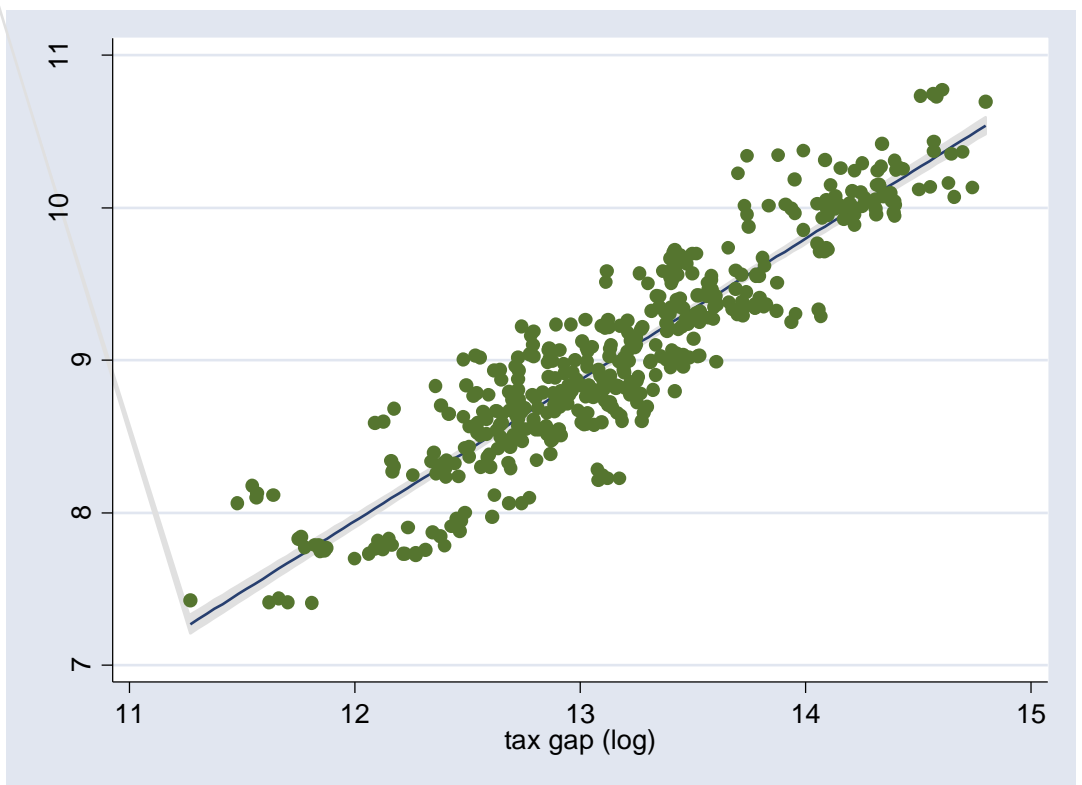

Following the theoretical framework and empirical analyses (Buonanno,2003) the explanatory variables are derived by socioeconomic, socio-demographic and deterrence factors. As usual, the expected return from the crime activity is affected by the deterrence variable. In this study we use three different measures for the probability of apprehension. The former is the share of crimes committed by unknown offenders to all recorded crimes in each category. A further deterrence variable used is the number of defendants convicted by a final judgment on a regional basis, weighted with the ratio between the number of crimes for which prosecution has begun and the same data in the region of origin. The third deterrence measured employed in our empirical analysis is the per capita number of police forces (police, Carabinieri, financial police, port authorities, prison guards and rangers) in each province available from the Ministry of Interior.

We use also several demographic variables. The percentage of men aged 15-29 years because they are supposed to be more prone to engage in criminal activities, and the regular component of immigration, both are normalized as share of population in the Italian provinces ${ }^{8}$ (Bianchi et al. 2012 and the literature quoted therein). The socioeconomic variables includes the value added per capita, the growth rate of the value added, the activity rate (both total and the female activity rate), the unemployment rate, as a proxy of the legitimate and illegitimate income opportunities, and the

\footnotetext{
${ }^{8}$ In models with fixed effects, many authors include population to control for population density as a further determinant of criminal activity.
} 
Gini coefficient to control for inequality. ${ }^{9}$ The importance of the availability of credit is "captured" by using a measure of the banks' non-performing loans. Specifically, we use the ratio of nonperforming loans on performing loans (source, Bank of Italy). A further financial variable included in the estimated models to test wealth effects are the per capita bank deposits in each province.

We also include in the analysis the education, defined as number of men aged 24-34, who have achieved at most a middle school diploma, for 100 men of the same age, and, as a policy variable, the expenditure for interventions and social services in the field of family and children, disabled, addictions, elderly, immigrants and nomads, homeless.

Finally, we test as an explanatory variables the personal consumption of drugs (Article 75, source ISTAT) and the number of doses of drugs seized to crime by the police. This latter variable is provided by Ministry of Interior and may capture an environment of lawlessness that affects criminal activity.

To avoid that the analysis is influenced by the size of the population in the different provinces, the crimes and the explanatory variables used in the models are normalized by the number of residents of the area, getting crime rates etc for $\mathbf{1 0 , 0 0 0}$ inhabitants. We used a double log model and followed a selection strategy from general to the particular.

\begin{tabular}{|l|l|l|}
\hline \multicolumn{2}{|l|}{ Table 3. Variables used in the models (unless otherwise specified, per capita variables are normalized per 10,000 } \\
\hline Variable & Source & Definition \\
\hline Crime & $\begin{array}{l}\text { ISTAT, Statistiche Giudiziarie e } \\
\text { Penali }\end{array}$ & $\begin{array}{l}\text { Per capita number of crimes against } \\
\text { property (robberies, thefts, car thefts), } \\
\text { frauds and usury reported to the } \\
\text { judicial authorities }\end{array}$ \\
\hline Propensity to evade & $\begin{array}{l}\text { Italian Revenue Agency (tax evasion; } \\
\text { reported tax base); ISTAT (value } \\
\text { added) }\end{array}$ & $\begin{array}{l}\text { Ratio between tax gap and tax } \\
\text { compliance (or value added) }\end{array}$ \\
\hline $\begin{array}{l}\text { Deterrence (1): crimes committed by } \\
\text { unknown offenders }\end{array}$ & $\begin{array}{l}\text { ISTAT- Statistiche Giudiziarie e } \\
\text { Penali } \\
\text { by a final judgment }\end{array}$ & $\begin{array}{l}\text { Ratio of crimes committed by } \\
\text { unknown offenders to all recorded } \\
\text { crimes in each category }\end{array}$ \\
\hline
\end{tabular}

\footnotetext{
${ }^{9}$ Inequality appears to be significantly associated with crime rates. See, for instance, Kelly (2000), Bourguignon (2001) and Fajnzylber et al (2002) amongst others. The data on the index of Gini for the Italian provinces were kindly provided by Sauro Mocetti (Bank of Italy) and Paolo Acciari (Ministry of Economics).
} 


\begin{tabular}{|c|c|c|}
\hline & & between the province and the region \\
\hline Deterrence (3): enforcement & Italian Ministry of Interior & $\begin{array}{l}\text { Per capita number of police forces } \\
\text { (Carabinieri; police; financial police, } \\
\text { port authorities, prison guards; } \\
\text { rangers). }\end{array}$ \\
\hline Young Men & ISTAT & The percentage of men aged 15-29. \\
\hline Population & ISTAT & Total resident population \\
\hline Immigration & ISTAT & $\begin{array}{l}\text { Regular component of immigration as } \\
\text { a share of population }\end{array}$ \\
\hline Value added & ISTAT & Per capita value added. \\
\hline Activity rate & ISTAT & Total activity rate. \\
\hline Unemployment rate & ISTAT & $\begin{array}{l}\text { Ratio between unemployed and labor } \\
\text { force. }\end{array}$ \\
\hline Gini coefficient & Acciari and Mocetti (2013) & $\begin{array}{l}\text { Gini coefficient calculated in each } \\
\text { province }\end{array}$ \\
\hline Non performing loans & $\begin{array}{l}\text { ISTAT elaborations on Bank of Italy } \\
\text { data }\end{array}$ & $\begin{array}{l}\text { Share of non-performing loans on } \\
\text { performing loans }\end{array}$ \\
\hline Bank deposits & Bank of Italy & Per capita value of bank deposits. \\
\hline Education & ISTAT & $\begin{array}{l}\text { Number of persons aged 25-34 who } \\
\text { have reached as maximum, the } \\
\text { middle school for } 100 \text { men of the } \\
\text { same age }\end{array}$ \\
\hline Social expenditure & ISTAT & $\begin{array}{l}\text { Per capita expenditure for } \\
\text { interventions for disabled, addictions, } \\
\text { elderly, immigrants, homless etc }\end{array}$ \\
\hline Drugs & Ministry of Interior & $\begin{array}{l}\text { Per capita consumption of drugs } \\
\text { (article 75) }\end{array}$ \\
\hline Drug doses & Ministry of Interior & $\begin{array}{l}\text { Per capita number of doses of drugs } \\
\text { seized by police forces. }\end{array}$ \\
\hline Illegal betting & $\begin{array}{l}\text { ISTAT, Statistiche Giudiziarie e } \\
\text { Penali }\end{array}$ & $\begin{array}{l}\text { Per capita number of crimes reported } \\
\text { to the judicial authorities against } \\
\text { illegal gambling laws }\end{array}$ \\
\hline
\end{tabular}

The existence of a causal link between all these explanatory variables and crimes has been widely investigated by the literature, here we use them in order to specify a model of crime determinant wherein tax gap has a role. However, the estimation of such models of crime produce relevant statistical problems (heteroskedasticity, multicollinearity, endogeneity etc.), that in our empirical framework we try to overcome. 


\section{Empirical framework}

The following model studies the impact of tax evasion on crime activity in a panel dataset of 101 provinces for 6 years (2006-2010):

$$
C_{i t}=\beta_{1} C_{i t-1}+\beta_{2} \text { Taxevasion }+\beta_{3} X_{i t}+\eta_{t}+c_{i}+u_{i t} \quad t=1, \ldots, T
$$

Equation (6) is the basic function of crime estimated by the literature, where $\eta_{t}$ is a separate time period intercept, $X_{i t}$ is a $1 x K$ vector of explanatory variables defined in the previous section, $c_{i}$ is the time-constant unobserved fixed effect and $u_{i t}$ are idiosyncratic errors. In summary, the econometric model follows the empirical model of the supply of crime initially proposed by Ehrlich (1973) and taken up by many other authors.

With regard to the dynamic features of the model, the literature assumes that there exists a significant relationship between crime rates in $\mathrm{t}$ and $\mathrm{t}-1$; hence the empirical models includes the lagged dependent variable $C_{i t-1}$. There may be several explanations for this dynamic relationship, not least the one that sees the persistence of the criminal activity as a learning-by-doing process which leads to a reduction of the costs of the criminal activity itself (see Buonanno and Montolio, 2008, for a survey).

These estimates for the criminal activity involve some statistical problems. Firstly, time invariant territorial characteristics (fixed effects) may be correlated with the explanatory variables. Secondly, since for several variables included in the vector $K$ causality may run in both directions with crime, these regressors may be correlated with the error term and endogeneity may arise. Thirdly, the presence of the lagged dependent variable $C_{i t-1}$ produces autocorrelation. Finally, a shortcoming of crime data is due to measurement error (under-reporting and so on). These panel data require an instrumental variable procedure able to take into account the model dynamics such as the GMM estimator suggested by Arellano and Bond (1991) and Arellano and Bover (1995). As well known, this instrumental variables estimator allows the use of multiple instruments to control for the endogeneity and the absence of ortogonality between the residuals and the regressors. Furthermore, the persistence of the dependent variable for one lag is able to eliminate the first order autocorrelation problem. Finally, the use of robust standard errors takes into account the presence of heteroskedastic errors. 


\section{Empirical results}

\subsection{Pooled OLS}

To better appreciate the complexity of the relationship under investigation, we first examine the link between propensity to evade and economic crime rates controlling for other potential crime determinants by a simple pooled OLS regression. Subsequently, we correct for model dynamics, joint endogeneity and measurement error by applying an instrumental variable estimator for panel data.

The basic OLS regression results are shown in Tables 4. The regressions are estimated using the pooled sample in levels, to explain criminal activities (property crimes, frauds and usury) in the Italian provinces.

The basic sample consists of 505 observations (5 years, 101 provinces) for the pooled levels. Nevertheless, data on Table 4 are referred to 460 observations because we have excluded from the sample the provinces of Piedmont and Valle d'Aosta, due to some inconsistency in the definition of the crimes in the original source of data, making the data of these provinces not comparable with the figures of the crimes of the other provinces.

We have also dropped other small provinces where the data were not available for all the years considered in the sample.

The results indicate that the propensity to evade does not show an appropriate sign for property crimes and it is not statistically significant in the usury regression. Amongst the additional regressors, the most important ones seem to be the regular immigrants and the Gini index, which are, as expected, positive and significant for all the economic crime models. A further statistically significant variable is the expenditure for interventions and social services, although with some ambiguous signs. The increase in social expenditure generates a positive growth in the number of property crimes reported to the judicial authorities, whereas it reduces the reported crimes in frauds and usury. Unemployment affects positively frauds and usury, whereas, strangely enough, it does not affect property crimes.

Regarding usury, financial variables are not statistically significant (a somewhat surprising result), while it is highly significant and positive the illegal betting. Caution should be exercised in analyzing these results: we use robust standard errors in the regression, so that the models are corrected for heteroscedasticity, but these panel data models need a further correction for the standard errors serial correlation. This might be the reason why our OLS standard errors are so small. 


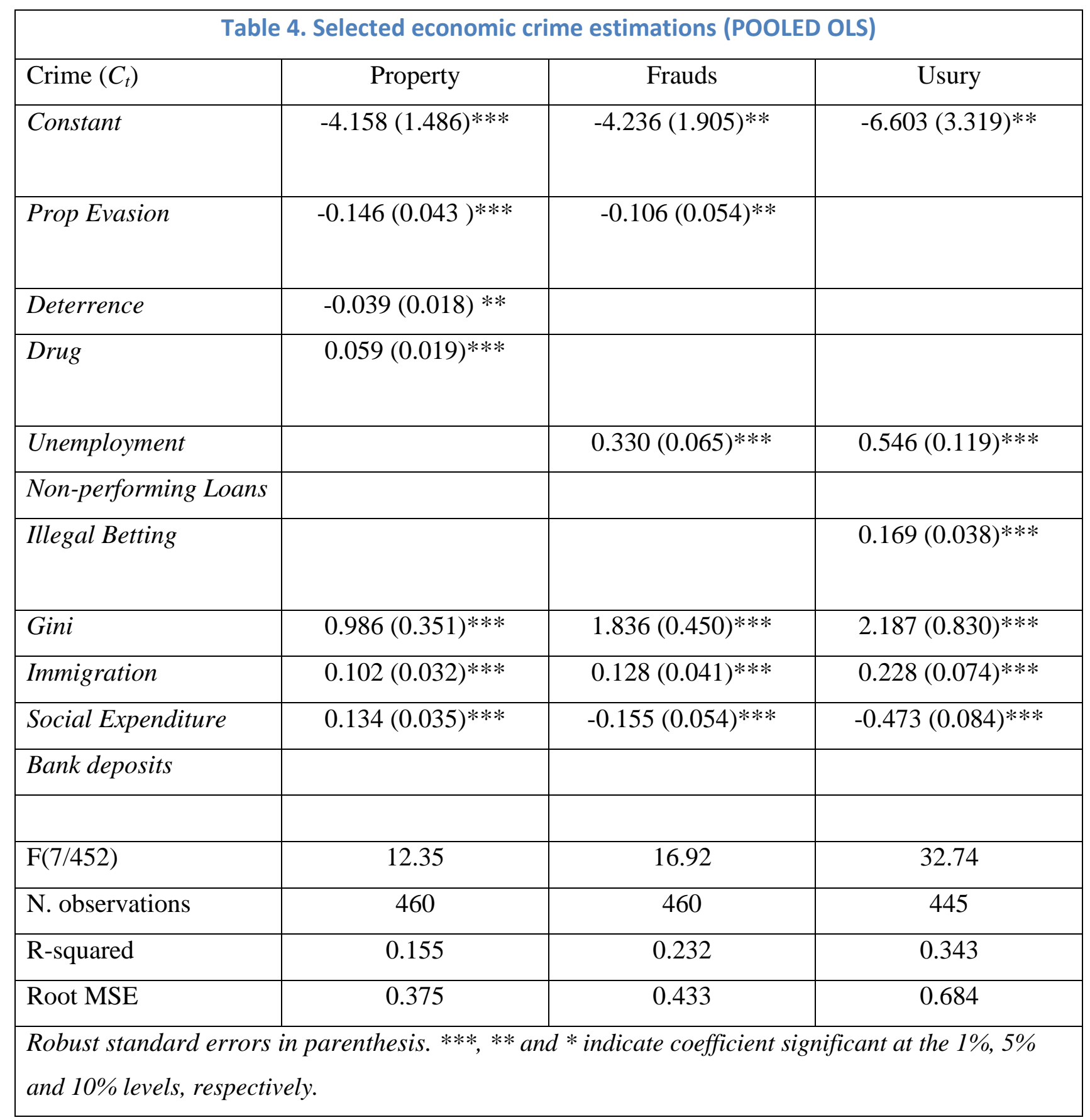

The evidence presented so far suggests that does not exist a robust correlation between economic crimes and tax evasion. However, the pooled regressions have several problems to be considered in order to verify that this absence of correlation is the result of estimation biases. The OLS estimates just discussed might be biased because of the possibility that crime rates themselves might affect the right-hand-side variables. For instance, illegal betting and tax evasion might be determined by usury, variables such as social spending and immigrants may be affected by all the crimes considered, whereas property crimes and drug consumption may be characterized by a two-way causality. Neglecting the joint endogeneity of the determinants provides inconsistent estimates. Moreover, it is very likely that the crime rates are measured with error and this latter might be 
correlated with some of the explanatory variables, in particular with the tax gap/value added ratio. It should be also remembered that the growth of the underground activity can generate a culture of illegality and this may affect the crime underreporting. Finally, these regressions do not take into account the possibility that crime tends to persist over time.

The following Table 5 reports alternative estimates obtained with a more appropriate model adapted to the requirements just listed, taking into account the lagged crime rates and accounting for crime measurement errors, and for jointly endogenous explanatory variables.

\subsection{Dynamic GMM}

Table 5 shows the GMM-system estimations for property crimes, frauds and usury in the Italian provinces. This estimator allows us to control for unobserved provincial-specific effects that are potentially correlated with our determinant of crime rates and to take into account dynamic and endogeneity aspects. In the estimation of property crime, reported in Table 5, all the variables are treated as endogenous, including the crime rates.

\begin{tabular}{|c|c|c|c|}
\hline \multicolumn{4}{|c|}{ Table 5 Selected economic crime estimations (GMM-system) } \\
\hline Crime $\left(C_{t}\right)$ & Property & Frauds & Usury \\
\hline$C_{t-1}$ & $0.728(0.068)^{* * *}$ & $0.690(0.115) * * *$ & $0.397(0.109)^{* * *}$ \\
\hline Prop Evasion & $0.073(0.020) * * *$ & $-0.106(0.049)^{* *}$ & $-0.313(0.092) * * *$ \\
\hline Deterrence & $-0.088(0.030) * * *$ & & \\
\hline Drug & $0.074(0.036)^{* *}$ & & \\
\hline Unemployment & & $0.187(0.143)^{* *}$ & \\
\hline Non-performing Loans & & & $0.262(0.101)^{* * *}$ \\
\hline Illegal Betting & & & $0.313(0.088)^{* * *}$ \\
\hline Hansen Test & 0.190 & 0.165 & 0.298 \\
\hline $\operatorname{AR}(1)$ & 0.084 & 0.002 & 0.000 \\
\hline $\operatorname{AR}(2)$ & 0.295 & 0.558 & 0.368 \\
\hline
\end{tabular}


In addition, consistently with our proposed theoretical interpretation, the sign of the propensity to tax evasion is negative for usury and frauds, whereas it is significant and positive for property crimes.

With regard to this latter, our explanation is related to the expected rewards from criminal activities that increases with tax evasion. As suggested in Section 2, the expected penalty declines with tax evasion: when the victim of the theft is a tax-evader he has less incentive to report the crime. In addition, tax evasion, acts on the property crimes as a wealth effect, in the sense that it is a signal of higher expected gains for the criminal. Moreover, tax evasion might also capture a redistributioninequality effect and thus generating an increase of thefts and robberies. Notice that in the OLS regression an inequality effect may be measured by the Gini coefficient, which is not statistically significant in the GMM model. Hence, inequalities may have a positive impact on criminal activity, but, controlling for endogeneity, this effect is captured only by tax evasion.. The positive sign of the tax gap coefficient may also concern the criminogenic environment that a coming from the underground economy. This latter can generate a culture of illegality where the potential gain from criminal is fully recognized.

Differently, for frauds and usury a substitution effect between tax evasion and crime emerges. This phenomenon is particularly relevant for usury, where the elasticity of substitution is quite high. This type of crime is more likely to affect small business owners, shopkeepers, tradesmen and professionals, namely those economic categories that are heavily involved in tax evasion and, at the same time, are themselves subject to credit rationing practised by the banking system on small firms. A similar picture emerges from the analysis of the activities of the victims of usury made by Cnel (2008), where it is shown that over $90 \%$ of the victims are related to small businesses (traders, entrepreneurs, artisans, professionals). The simple model reported in Section 2 basically serves to highlight the relationship between illegal financing, bank credit and tax evasion. According to this simple scheme, our estimates carried out through our measure of propensity to evade indicate a negative relationship between usury and tax evasion. Since tax compliance is a positive function of income, this result may imply that the demand for illegal loans is countercyclical. This is a distinctive character of usury compared with "bank credit", which is pro-cyclical. Similarly, there is a substitution effect also for frauds: given the information asymmetries that characterize this economic crime, the hypothesis tested concerns agents that have less need for defrauding insurance markets of the automobile, health care, unemployment etc. if they can defraud the state with tax evasion. For instance, literature has highlighted as causes of the rapid growth of insurance fraud factors such as the change in morality, the modification in the behaviour of some intermediaries (medical doctors, mechanics etc), insurers' attitudes (see, Dionne 2012 amongst others). 
Nevertheless, our empirical analysis shows that once one finds the gaming system to defraud the tax authority becomes less compelling to defraud, for instance, in the insurance markets.

\subsection{Deterrence}

The deterrence variables concern the cost side of the economic crime models, through the probability of being caught in undertaking a criminal offence. The significance of these measures have important policy implications on crime prevention. Many empirical studies use, in this regard, the ratio of crimes committed by unknown offenders to all recorded crimes in each category. We have used this indicator in our estimates, but without success; moreover it should be noted that the denominator of this ratio is part of the dependent variable that we aim to explain.

As described above, we halve tested several other deterrence variables concerning imprisonment and detection, arrest and conviction. However, we find statistical significance and the expected sign only for the per capita number of police forces in each province in the case of property crimes, whereas frauds and usury are not influenced by any deterrence or clearing-up variable. ${ }^{11}$ This lack of significance may be due to the increased difficulty of intervention and prevention of economic crimes in Italy. This phenomenon is probably linked to the some inefficiencies of the institutions responsible for the prevention and repression of crime, and to similar problems of the judicial Italian judicial system. It follows that in Italy, unlike most of the empirical analysis, ${ }^{12}$ for these types of economic crimes, deterrence variables (certainty of conviction and/or clear-up rates) have a very limited role, and it is important to emphasize the fact that the variable used in the estimated models includes not only the police and Carabinieri, but also financial police, port authorities and rangers.

Thus, this relationship between some crimes and the deterrence variables has important policy and political implications.

\subsection{The socio-demographic variables}

Among demographic and socioeconomic variables only unemployment significantly affects frauds. This is a troublesome result, since economic literature on crimes usually emphasizes that labour market conditions have a positive explanatory power especially with regard to property crimes (Altindag, 2012). However, the effects of unemployment on crimes have been recently debated and, for Italy, Buonanno (2005) finds that it significantly affects crimes only in southern regions.

\footnotetext{
${ }^{11}$ Deterrence variables are also not significant for fraud and usury crimes in the basic OLS pooled regression.

${ }^{12}$ See Marselli and Vannini (1997) for Italy and Entorf (2012) for a survey.
} 
Focusing on fraud crime, unemployment probably involves elements of labor demand or opportunity costs of participating in this illegal activity (in the absence of work and income, more people are available to commit fraud) and supply, as the unemployed persons are a fragile component of society, and therefore more susceptible to this type of crime. Certainly, unemployed people do not have an income and they cannot evade taxes. In this view the unemployment rate in a province is a complementary indicator of income opportunities available in the legal labor market. If these opportunities are scarce, frauds can only increase and labor supply is entirely allocated in the illegal market.

With regard to the property crimes, the estimates provide a significant coefficient for the personal consumption of drugs, indicating the drug use as a motivation for thefts and robberies..

Usury is related to the illegal betting. The share of per capita income used, in the provinces, for consumption of gambling is an indicator highly significant to analyze the exposure to debt and to the risk of the crime of usury. The positive sign found for illegal betting represents a further need for illegal financing, certainly not permitted by the banking system.

Our estimates exclude many of the explanatory variables listed in Section 4, because of their statistical insignificance or because of collinearity problems. Therefore, important variables such as the percentage of men aged 15-29, immigration and education, that the literature on Italy has previously investigated (Buonanno and Leonida 2006; Bianchi et al 2008), have no role in our estimated model. ${ }^{13}$ However, many of these variables (immigration, population, education, bank deposit etc.) have been used as instrument in the GMM-system. Moreover, we estimate a fixedeffect model and, therefore, the unobserved province effect might include certain demographic feature of the population (age, education): people living in different provinces might have different attitudes toward economic crimes, that are typically slow to change. Finally, we have not even found statistical significance for the time dummies.

\subsection{The credit market and usury}

\footnotetext{
${ }^{13}$ See Bell and Machin (2013) for a survey on immigration and crime.
} 
Consistently with the model sketched in Section 2, usury does seem correlated with our credit variable (the ratio between non-performing and performing loans). ${ }^{14}$ Thus, the condition on credit market are important for this crime (the estimated elasticity is rather high) and the malfunctioning of the circuit of credit facilitates usury, pushing intermediaries to ration borrowers considered most unreliable. This is the case of families with low and middle income, small and medium businesses that are undercapitalized because they declare to the tax authorities only a part of their goods and services and companies operating in the most deprived areas and in the areas most at risk. In this context, the lenders limit the supply of additional credit to the borrowers who demand funds, even though the latter are willing to pay higher interest rates.

These borrowers, that are not able to offer a full guarantee to cover their debt in the event of project failure, are implicitly declaring the probability of success to be low. In a context of adverse selection, the main party interested in offering a guarantee (the collateral) is the borrower with the most secure project. The high elasticity of substitution between tax evasion and the number of crimes for usury reported to the judicial authorities, bring us to envisage a considerable degree of substitution between self-financing (tax evasion) and external financing (usury) with important policy implications. The theoretical model and the estimates obtained in this study lead us to the conclusion that policy enforcement should be implemented simultaneously on both the illegal credit and tax evasion. Of course, the negative relationship between usury and tax evasion does not mean that the contrast to tax evasion increases crime: usury is not triggered by the lack of evasion rather than by credit market constraints. Hence, in the presence of an effort by the Government to remove the barriers of access to the credit market in particular for micro and small business, the use of tax evasion as a self-financing device would be discouraged.

\subsection{The costly learning process}

The significance of the lagged value of crime rate in the estimated models indicates that the dynamic specification used is appropriate: there exists a persistence of crime in the Italian provinces, particularly for the property crimes and frauds (with a coefficient of the lagged dependent variable of about 0.70 ). Thus, the experience in a affects the decision to commit a crime in the future. Therefore, in these types of crime there exists a sort of learning-by-doing process, which reduces the costs of these illegal activities. The persistence effect is less intense for usury, showing a lower degree of inertia compared to the other two crimes considered.

\footnotetext{
${ }^{14}$ Sapienza (2013) estimates a panel for the period 2004-2008 relative to some Italian Southern regions, finding that bank credit to households strongly (and negatively) affects the number of crimes of usury, confirming the relationship between legal and illegal supply of credit.
} 
In an interpretation of adjustment costs, the dynamic model shows that the level of crimes committed does not instantly adjust to changing in the determinants of crime. These latter are gradually considered by criminals, as it is expensive to adjust quickly to change, requiring a learning process:

$$
\Delta C_{i t}=C_{i t}-C_{i t-1}=\lambda\left(C_{i t}^{*}-C_{i t-1}\right) \Rightarrow C_{i t}=\lambda C_{i t}^{*}+(1-\lambda) C_{i t-1}
$$

Where $0 \leq \lambda \leq 1$ is the speed of adjustment and $C_{i t}^{*}$ is the goal (or desired) level of crime. Following this interpretation, we can see that the adjustment of usury is much faster than that for crimes on property and frauds.

\subsection{The role of the tax burden}

In the construction of the propensity to evade may be also used the value added of each province, although the use of compliance is more correct, because it is the true tax base (the value added incorporates an estimate of the underground economy), and because the value added data do not take into account the difference between the firms' production area and their registered office. The following Table 6 shows the GMM estimates of the three crimes considered, measuring the propensity to evade by the ratio between tax gap and value added.

\begin{tabular}{|l|c|c|c|}
\hline \multicolumn{3}{|c|}{ Table 6 Selected economic crime estimations (GMM-system) Prop Evasion with Value Added } \\
\hline Crime $\left(C_{t}\right)$ & Property & Frauds & Usury \\
\hline$C_{t-1}$ & $0.704(0.074)^{* * *}$ & $0.575(0.172)^{* * *}$ & $0.420(0.108)^{* * *}$ \\
\hline Prop Evasion with & $0.127(0.032)^{* * *}$ & $-0.195(0.101)^{* *}$ & $-0.642(0.224)^{* * *}$ \\
Value Added & & & \\
\hline Deterrence & $-0.065(0.025) * * *$ & & \\
\hline Drug & $0.073(0.037)^{* *}$ & & $0.252(0.102)^{* * *}$ \\
\hline Unemployment & & $0.161(0.084)^{* * *}$ & \\
\hline Non-performing Loans & & & $0.279(0.086)^{* * *}$ \\
\hline Illegal Betting & & & \\
\hline Hansen Test & & & \\
\hline
\end{tabular}




\begin{tabular}{|l|c|c|c|}
\hline AR(1) & 0.092 & 0.001 & 0.000 \\
\hline AR(2) & 0.292 & 0.585 & 0.342 \\
\hline N. observations & 368 & 368 & 302 \\
\hline N. instruments & 63 & 15 & 35 \\
\hline Lags & $\mathrm{L}(0 / 3)$ & $\mathrm{L}(3 / 4)$ & $\mathrm{L}(2 / 3)$ \\
\hline Robust standard & & \\
\hline
\end{tabular}

Robust standard errors in parenthesis. ***, ** and * indicate coefficient significant at the 1\%, 5\% and $10 \%$ levels, respectively.

Property (instruments): population; immigration; activity rate.

GMM-type instruments: property crime; propensity to evasion; deterrence; consumption drug.

Frauds (instruments): population; immigration; activity rate, pc value added, Education, Social expenditure.

GMM-type instruments: fraud crime; propensity to evasion.

Usury (instruments): population; bank deposits; activity rate.

GMM-type instruments: usury crime; propensity to evasion; illegal betting; non-performing loans.

The results are similar to those of Table 5 (with propensity to evade measured through the ratio between tax gap and tax compliance), with the exception of the coefficient of the propensity to evade, which in the case of usury shows a much greater elasticity $(-0.642$ against -0.313 in the estimate with the tax compliance).

As stressed in Section 4, this way of interpreting the effect of the propensity to evade is instructive, as it allows us to identify a first component which is the propensity to evade in terms of tax compliance, the tax gap/tax compliance ratio, and a second component which is a measure of the tax burden (see, equation 5). The highest elasticity found for tax evasion in Table 6 , shows that the substitution effect (willingness to evade) increases with the tax burden: ceteris paribus, the higher the tax burden, the more the individual opts for evasion rather than usury and frauds. Similarly, a higher tax burden generates strong redistributive effects with greater inequalities, thus affecting property crimes.

\section{Concluding remarks}

In this paper, we investigate the impact of tax evasion on some criminal activities in the Italian provinces during the period 2006-2010. A set of hypothesis has been tested by using a GMM- 
system estimator, an instrumental approach that takes into account the dynamic properties of a data set and controls for measurement errors and joint endogeneity of the explanatory variables.

We have seen that the economic crimes here considered (theft and robberies, frauds and usury) are strongly influenced by tax evasion. In a country like Italy, characterized by a large share of underground economy and tax evasion, both these phenomena also affect economic crimes. In particular, for usury and frauds tax evasion represents an alternative source of financing with respect to illegal job (frauds) or criminal financing (usury), whereas for the crimes against property the increase in tax evasion generates a growth of the crime. The effect of tax evasion is particularly relevant for usury. This crime, together with frauds, shows a lower inertia (or a coefficient of speed of adjustment very high) with respect to property crimes.

The estimates also show that the substitution effect (willingness to evade) increases with the tax burden: ceteris paribus, the higher the tax burden, the more the individual chooses tax evasion rather than usury and frauds.

Finally, in Italy, unlike most of the empirical analysis, for these types of economic crimes deterrence variables (certainty of conviction and/or clear-up rates) have a very limited role.

These results pose serious problems of policy. It is clear from our estimates that the fight against tax evasion cannot be separated from the contrast to illegal credit and frauds, and that the problems of usury cannot be uncoupled from those of credit rationing and the Italian production structure. This latter is made of a lot of small and micro firms, which make a large use of tax evasion and tax avoidance, due both to high tax burden (the effective one is more than 50\%) and inefficiencies of the mechanism adopted to estimate the taxable income of small firms, the self-employed and professionals (Sector Studies - "Studi di Settore”).

Therefore, a Government's agenda focused on the contrast of economic crimes cannot prescind from a more efficient tax audit activity based not only on sanctions but also on a spontaneous fulfilment of tax compliance. 


\section{Appendix}

\section{Tax gap: definition and methodology of calculation}

To test the existence of the relationship between criminal activity and tax evasion we use the measure of tax gap calculated by the Revenue Agency on provincial base. The overall tax gap is a complex variable derived by the sum of the tax gaps in IRAP (Regional Tax on Productive Activities), VAT, income and profit tax. ${ }^{15}$

The tax gap estimated for Italy by the Italian Revenue Agency (hereinafter RA), is defined as the difference between the potential collection and the tax that is actually paid. ${ }^{16}$ There exists a number of methods to calculate tax gap, which rely on the available information, the tax law and the economic structure. ${ }^{17}$ The RA adopts a top-down approach, based on the comparison between tax data and National Accounts figures, provided by Italian National Institute of Statistics (ISTAT). These latter provide an indicator of the "potential" tax base, but they also incorporate an estimate of the underground economy. From this potential base an estimate of the potential collection is then derived, through which it is possible to calculate the tax gap ${ }^{18}$. The Italian tax gap relies mainly on two key tributes: VAT and IRAP.

The similarity between the IRAP tax base and National Account value added is remarkably important in the study of the tax gap. In fact, the National Accounts are the basic unit that determines GDP and, therefore, they contain all the incomes that generate the change of the wealth of a country. It follows that the IRAP tax base encompasses much of the tax base resulting from the

\footnotetext{
${ }^{15}$ VAT (value added tax) is an internationally standardized tax whereas IRAP is the Italian acronym of the regional tax on productive activities, created in 1997: this is a tax whose tax base is represented by the firms' revenues net of purchases before labor costs (with some differences related to the type of the employee contract) and financial expenses. For a detailed analysis of the construction of the tax gap see Pisani (2014), Braiotta et al (2013) and D’Agosto et al (2014).

${ }^{16}$ The RA has adopted a methodology to estimate potential collection, the amount "which could be collected if no taxpayers would voluntary breach the law and involuntary errors would amount to zero" see Das-Gupta, Mookherjee (2000).

${ }^{17}$ For a summary, refer to OECD (2002). See also HMRC (2012). See also Pisani (2014).

${ }^{18}$ The adopted methodology is based on international best practices (see, among others, HMRC, 2012).
} 
production of goods and services. In addition, the large number of taxpayers subject to this tax means that the IRAP tax base gap represents a macro indicator of the value added concealed from tax authorities.

As mentioned before, the RA uses a top-down approach to calculate the gap, comparing (after having proceeded with the harmonization of the two quantities) the IRAP tax base inferred from the tax returns with the National Accounts value added at factor cost.

With regard to the VAT, in order to obtain an accurate measure of the potential liability, it is necessary to identify both taxable base and suitable legal VAT rates with respect to the legislation. ${ }^{19}$ Next, the VAT gap can be derived and includes tax evasion, the deliberate intention to fraud, insolvency, negligent acts and misinterpretation of the law.

The taxpayer voluntary compliance is calculated from the VAT revenues on accrual basis. These represent the VAT revenues that an economic system generates as a result of transactions burdened by VAT in the reference period (a fiscal year). The theoretical VAT base, consistent with the classifications and definitions applied for the declared VAT base, is calculated to estimate base gap. The total tax base (BIT) is estimated from detailed expenditure subclasses of National Accounts macro-cluster components: Households, General Government and Uses for Market Enterprises.

The RA requires highly detailed National Accounts aggregates in order to capture the complex system of VAT regulation and to calculate accurate theoretical base. For each detailed subclass of National Accounts is deducted the share of exempted base; then to the residual amount is associated its own proper statutory VAT rate. The VAT gap is estimated by deducting from the potential liability the VAT revenues.

From the point of view of economic analysis, the VAT gap captures the phenomenon at the time of consumption, whereas the IRAP tax gap is focused on the time of production. This differentiation is very important for the spatial analysis, since some areas of the country have a large concentration of production plants, while others are characterized primarily as a place of consumption. It is possible, therefore, that the evasion that is formed in the first ones turns in purchasing power in the second ones

Finally, the tax gap for income and profit tax is estimated starting from the IRAP tax gap. In fact, if the labor cost of undeclared employees is subtracted from the IRAP base gap, it is obtained, by definition, an estimate of the corresponding gap in the gross profit. Hence, by applying appropriate

\footnotetext{
${ }^{19}$ See D'Agosto et al (2014) for details.
} 
fiscal rate to the gap in gross profit, it is derived an estimate of the corresponding tax gap. The overall tax gap is equal to the sum of the tax gaps in: IRAP, VAT; income and profit tax.

\section{References}

- Agenzia delle Entrate (2010), Dieci Anni dell'Agenzia delle Entrate, Roma.

- Altindag D. T. (2012), Crime and unemployment: Evidence from Europe, International Review of Law and Economics, 32, 145-157.

- Arellano M. and Bond S. (1991), Some tests of specification for panel data: Monte Carlo evidence and application to employment equation, Review of Economic Studies, $58,277-97$.

- Arellano M. and Bover O. (1995), Another look at the instrumental-variable estimation of error components models, Journal of Econometrics, 68, 29-52.

- Bell B. and Machin S. (2013), Immigration and crime, in Constant A.F. and Zimmermann K.F. (eds), International Handbook on the Economics of Migration, Edward Elgar Publishing, Cheltenham UK.

- Bianchi M., Buonanno P. and Pinotti P. (2012), Do immigrants cause crime?, Journal of the European Economic Association , 10, 1318-47.

- Bourguignon F. (2001), Crime as social cost of poverty and inequality: A review focusing on developing countries, in Yusuf S, Evenett S. and Wu W. (eds.), Facets of Globalization: International and Local Dimensions of Development. Washington DC, World Bank.

- Braiotta A., Pisani S., Pisano E. (2013) Evasione fiscale e distribuzione primaria del reddito, Rivista di diritto finanziario e scienza delle finanze, n.2.

- Buonanno P. (2003), The socioeconomic determinant of crime. A review of the literature, Working Paper 62, University of Milan Bicocca.

- Buonanno P. (2005), Crime and Labour Market Opportunities in Italy (1993-2002), Working Papers Università degli Studi di Bergamo, Dipartimento Scienze Economiche N.4. 
- Buonanno P., Leonida L. (2006), Education and crime: evidence from Italian regions. Applied economic letters vol. 13, (11), 709-713.

- Buonanno P. and Montolio D. (2008), Identifying the socioeconomic determinants of crime across Spanish provinces, International Review of law and Economics, 28, 89-97.

- Cracolici M.F. and Uberti T.E. (2009), Geographical distribution of crime in Italian provinces: A spatial econometric analysis, Jahrbuch fur Regionalwissenschaft, 29, 1-28.

- Cnel (2008), Rapporto sull’Usura. Diffusione territoriale, evoluzione e qualità criminale del fenomeno. Roma. Settembre.

- Das-Gupta A., Mookherjee D. (2000) Incentives and institutional reform in tax enforcement an analysis of developing country experience. Lavoisier.

- Dionne G. (2012), The empirical measure of information problems with emphasis on insurance fraud and dynamic data, CIRPEE WP. 12-33, Montreal.

- D'Agosto E., Marigliani M., Pisani S. (2014), Asymmetries in the territorial VAT gap, Italian Revenue Agency, Discussion Topics, N.2.

- Ehrlich I. (1973), Partecipation in illegitimate activities: an economic analysis, NBER, NY 68-134.

- Entorf H. (2012), Certainty and Severity of Sanctions in Classical and Behavioral Models of Deterrence: A Survey, IZA DP No. 6516.

- Fajnzylber P., Lederman D. and Loayza N. (2002), Inequality and violent crime, Journal of law and economics, XVL 1-40.

- Freeman R. B. (1999), The economics of crime, in O. Ashenfelter and D. Card (eds), Handbook of Labor Economics, Vol. 3, Elsevier Science, The Netherlands.

- HMRC, (2012), Measuring tax gaps 2012, HM Revenue \& Customs, October, London. Internal Revenue Service 2012.

- Karni, E., "Fraud" in Eatwell, John et al.(Eds), the New Palgrave: Allocation, Information and Markets, Macmillan Press Limited, 1989.

- Kelly M. (2000), Inequality and crime, Review of Economics and Statistics, 82, 530-539.

- IRS releases new tax gap estimates January, Washington.

- Marselli R. and Vannini M. (1997), Estimating a crime equation in the presence of organizated crime: Evidence from Italy, International Review of law and Economics, 17, 89113.

- Ministero dell'Economia e delle Finanze (2013), Nota di Aggiornamento del Documento di Economia e Finanza 2013, Roma. 
- OECD, (2002). "Measuring the Non-Observed Economy: a Handbook"

- Pisani S. (2014) Tax gap and the performance of Italian Revenue Agency. An ongoing project, Discussion Topics, Italian Revenue Agency, n.1.

- Roodman D. (2009), How to do xtabond2: An introduction to difference and system GMM, in Stata Journal 9, N.1, 86-136.

- Sapienza E. (2013), Usura ed estorsione nel mezzogiorno: Una stima delle determinanti, Studi Economici, 1, 45-67. 